\title{
CONTROLLED TRIAL OF THE EFFECT OF COMPLETE IMMOBILIZATION OF THE JOINTS IN RHEUMATOID ARTHRITIS
}

\author{
BY \\ R. E. H. PARTRIDGE AND J. J. R. DUTHIE \\ Rheumatic Diseases Unit, Northern General Hospital, Edinburgh, and \\ Department of Medicine, Edinburgh University
}

It has long been accepted by the majority of physicians that rest in bed forms an important part of the treatment of rheumatoid arthritis during the active phase of the disease, but sharp differences of opinion have been expressed as to the correct treatment of inflamed joints during this phase. John Hunter (1835) stated that "nothing can promote the contraction of a joint so much as motion before the disease is removed". Hugh Thomas (1878) advocated immobilization of inflamed joints, and maintained that even after prolonged fixation movement would return if cartilage was present in the joints. Sir Robert Jones (1909) warned against excessive movement of inflamed joints. The fear of ankylosis, however, has led many authorities to advocate a combination of splinting and active movement. Swaim (1934) was a pioneer in the use of light plaster of Paris splints to relieve pain and prevent deformity. These splints were moulded to the joints and did achieve complete immobilization, thus relieving both pain and muscle spasm. Nevertheless, Swaim believed that it was dangerous to leave these splints in place for more than 48 hours. He recommended daily movements after this initial period to prevent the formation of adhesions. Kindersley (1936) reported that he had immobilized inflamed joints for 2 weeks in unpadded plaster and noted reduction in signs of joint inflammation and muscle spasm. At the end of this period the majority of patients rapidly regained full movements; in others, however, the joints were stiff and in a few cases manipulation was needed to restore movement. He suggested that the bad reputation of this type of treatment might have been due to the use of padded wooden or metal splints which were never effective in achieving complete immobilization of a joint. Kindersley himself, however, later came to believe that the immobilization of inflamed joints for a week or more was contraindicated.
Duthie (1951, 1952) suggested that pain and swelling of a joint subsided more rapidly and completely if the joint were immobilized for 1 to 3 weeks. A regimen of continuous immobilization of joints for a period of up to 3 weeks has been advocated by Kelly (1953, 1956, 1957, 1960), who recommended that patients should remain ambulatory during the time the inflamed joints were immobilized, with active movements of the unaffected joints. Swanson (1956) found that immobilization of acutely inflamed joints for 3 weeks controlled symptoms and was accompanied by an increase in well-being and diminution of the systemic manifestations of the disease.

It seemed that the value and possible hazards of complete immobilization could only be assessed by a clinical trial designed to compare the progress of two groups of patients: one in which the joints were immobilized for a standard period of time, followed by graduated resumption of activity, and the other treated along more orthodox lines.

\section{Material}

68 patients were admitted to the trial. All were classified as cases of "definite" or "classical" rheumatoid arthritis, according to the criteria of the American Rheumatism Association (Ropes, Bennett, Cobb, Jacox, and Jessar, 1959). Apart from this, no special conditions for admission to the trial were laid down and patients in all stages of the disease were accepted. The sensitized sheep cell test was positive in 46 of them (68 per cent.) and radiological changes of erosive arthritis were present in 55 (81 per cent.). Five patients were both radiologically and serologically negative, but were classed on clinical grounds as "definite" cases of rheumatoid arthritis. Joint involvement was multiple and bilateral in all cases and rheumatoid nodules were present in 23 patients.

Half the patients were placed in the group to be immobilized (the "rest" group) and the other 34 in the control group, by random allocation. 


\section{Methods}

Patients in the rest group were confined to bed for 4 weeks. Unpadded plaster splints were applied to the arms and legs and fixed in position by circular cuffs, effectively immobilizing the joints of all four limbs except the shoulders and hips. No physiotherapy was given during this period and the splints were removed only if a new set was needed.

Patients in the control group were largely confined to bed for 4 weeks, but they were allowed up for toilet purposes. Unpadded plaster rest splints were applied to the arms and legs and removed twice daily for general maintenance exercises and active joint movements. All patients in both groups were given calcium aspirin, 60-80 gr. daily. At the end of 4 weeks, complete immobilization was terminated in the rest group and thereafter both groups of patients were treated along the same lines, with resumption of weight bearing and more active forms of physiotherapy.

Clinical assessments, laboratory tests, strength of grip, and measurements of range of movement were made on admission and at 4, 6, 12, and 24 weeks.

The criteria for grading functional capacity and disease activity were those used by Duthie, Brown, Knox, and Thompson (1957) and are reproduced in Tables I and II.

TABLE I

GRADES OF FUNCTIONAL CAPACITY

\begin{tabular}{c|c|c}
\hline Grade & \multicolumn{1}{c|}{ Definition } & \multicolumn{1}{c}{ Remarks } \\
\cline { 1 - 3 } I & Fit for all normal activities & $\begin{array}{l}\text { Full employment in usual } \\
\text { work } \\
\text { Full household duties }\end{array}$ \\
\cline { 1 - 3 } III & Moderate Restriction & $\begin{array}{l}\text { Usual employment with } \\
\text { modifications } \\
\text { Light or part-time work } \\
\text { No dependency on others }\end{array}$ \\
\hline IV & Confined to Chair or Bed & $\begin{array}{l}\text { Only very light work or } \\
\text { housework } \\
\text { Some degree of dependency } \\
\text { on others }\end{array}$ \\
$\begin{array}{l}\text { Not capable of any work } \\
\text { Completely dependent on } \\
\text { others }\end{array}$ \\
\hline
\end{tabular}

Peripheral Blood Examination.-The methods for estimating haemoglobin $(\mathrm{Hb})$ and erythrocyte sedimentation rate (E.S.R.) were the same as those described by Richmond, Gardner, Roy, and Duthie (1956). 100 per cent. haemoglobin was equivalent to $14.8 \mathrm{~g}$. $\mathrm{Hb} / 100 \mathrm{ml}$. blood.

Sensitized Sheep Cell Agglutination Test (S.C.A.T.).This was performed by the method of Ball (1950) and modified by the use of M.R.C. haemagglutination plates in place of test tubes. A titre of $1 / 128$ was designated as the lowest indicating a positive result.

Range of Joint Movement.-This was measured by a long-arm protractor, using three fixed bony points in relation to each joint. Measurements were made of the range of flexion and extension in the knees, elbows, ankles, and wrists in each case. Limitation of extension at the elbows and knees was measured when present. The measurements were all made by one observer.

Strength of Grip.-A bag of appropriate size was connected to a mercury manometer and the bag inflated to $30 \mathrm{~mm}$. $\mathrm{Hg}$; the best result of three attempts was recorded for each hand.

\section{Results}

Three patients in each group were lost from the trial and have been excluded from the analysis of results. One female and one male in the rest group failed to report for assessment after Week 6 and Week 12 respectively, and one female in this group died of an unknown cause during the first 6 months. Three males in the control group did not attend for assessment after Week 6. The characteristics of the two groups on admission, after exclusion of these patients, are shown in Table III (opposite).

Range of Joint Movement.-Measurements made in the rest group within a few hours of removal of

TABLE. II

DEGREES OF DISEASE ACTIVITY

\begin{tabular}{|c|c|c|c|c|}
\hline Degree of Activity & $\begin{array}{c}\text { Erythrocyte } \\
\text { Sedimentation Rate } \\
(\mathrm{mm} . / 1 \mathrm{hr})\end{array}$ & $\begin{array}{l}\text { Haemoglobin } \\
\text { (per cent.) }\end{array}$ & Joint Involvement & Systemic Disturbance \\
\hline Inactive & 20 or Under & 85 or Over & $\begin{array}{l}\text { No symptoms due to joint } \\
\text { inflammation }\end{array}$ & None \\
\hline Moderately Active & $20-60$ & $65-84$ & $\begin{array}{l}\text { Signs of inflammation in } \\
\text { several joints }\end{array}$ & Moderate, but weight steady \\
\hline Very Active & Over 60 & 64 or Under & $\begin{array}{l}\text { Signs of acute inflammation in } \\
\text { many joints }\end{array}$ & Marked, with loss of weight \\
\hline
\end{tabular}


TABLE III

COMPOSITION OF GROUPS INCLUDED IN THIS STUDY

\begin{tabular}{|c|c|c|c|c|c|c|c|c|}
\hline \multirow{2}{*}{\multicolumn{2}{|c|}{$\frac{\text { Group } \quad \ldots \quad \ldots}{\text { Number of Patients }}$}} & \multicolumn{2}{|r|}{. } & \multicolumn{2}{|c|}{$\ldots$} & $\cdots$ & Rest & Control \\
\hline & & $\cdots$ & $\cdots$ & . & . & $\cdots$ & 31 & 31 \\
\hline \multirow{2}{*}{ Sex } & Female & $\cdots$ & $\cdots$ & . & . & $\cdots$ & 17 & 18 \\
\hline & Male & $\cdots$ & $\cdots$ & - & . & $\cdots$ & 14 & 13 \\
\hline \multicolumn{3}{|c|}{ Age (yrs) (mean \pm S.D.) } & $\cdots$ & . & . & $\cdots$ & $51 \pm 10$ & $51 \pm 12$ \\
\hline \multirow{3}{*}{\multicolumn{3}{|c|}{ Duration of Symptoms (yrs). }} & & $<$ & 2 & $\cdots$ & 3 & 7 \\
\hline & & & $\cdots$ & $2-5$ & & $\cdots$ & 18 & 14 \\
\hline & & & & $>$ & 5 & $\cdots$ & 10 & 10 \\
\hline \multicolumn{7}{|c|}{ Haemoglobin Level (per cent.) (mean \pm S.D.) } & $87 \pm 9$ & $82 \pm 10$ \\
\hline \multicolumn{7}{|c|}{$\begin{array}{llll}\text { E.S.R. }(\mathrm{mm} . / 1 \mathrm{hr})(\text { mean } \pm \text { S.D. }) & \ldots & \ldots\end{array}$} & $45 \pm 23$ & $52 \pm 24$ \\
\hline \multirow{2}{*}{ S.C.A.T. } & \multicolumn{2}{|c|}{ Positive .. } & & $\because$ & $\cdots$ & 23 & 17 \\
\hline & \multicolumn{2}{|c|}{ Negative .. } & . & & . & $\cdots$ & 8 & 14 \\
\hline \multirow{2}{*}{$X$ Rays } & \multicolumn{2}{|c|}{ Positive .. } & $\cdots$ & & 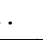 & $\cdots$ & 26 & 24 \\
\hline & \multicolumn{2}{|c|}{ Negative... } & $\cdots$ & & . & $\cdots$ & 5 & 7 \\
\hline
\end{tabular}

the splints showed a significant decrease in mean range of movement in many joints (Table IV). This was most marked in the wrists and knees (mean decrease $30^{\circ}$ and $59^{\circ}$ ), movement in the elbows and

TABle IV

CHANGES IN MEAN RANGE OF JOINT MOVEMENT IN THE REST GROUP BETWEEN ADMISSION AND WEEK 4

\begin{tabular}{|c|c|c|c|c|}
\hline \multirow{2}{*}{$\begin{array}{c}\text { Time } \\
\text { of } \\
\text { Assessment }\end{array}$} & \multicolumn{4}{|c|}{ Mean Range in Degrees \pm S.D. } \\
\hline & Wrists & Elbows & Knees & Ankles \\
\hline Admission & $83 \pm 28$ & $139 \pm 22$ & $125 \pm 25$ & $66 \pm 12$ \\
\hline Week 4 & $53 \pm 31$ & $115 \pm 34$ & $66 \pm 39$ & $57 \pm 13$ \\
\hline
\end{tabular}

ankles being less affected (mean decrease $24^{\circ}$ and $9^{\circ}$ ). The previous mean range of movement had been regained by Week 6, i.e. 2 weeks after removal of the splints.

Table $\mathrm{V}$ shows the change in mean range of movement for the joints in both groups at each assessment. A small increase in mean range of movement occurred in the case of elbow, knee, and ankle joints in the rest group and in the elbow and ankle joints of the control group. None of these changes was statistically significant and there was no significant difference between the two groups.

Table VI (overleaf) shows the changes in range of movement of individual knee joints between admission and Week 12, differentiating between joints with normal movement on admission and those in which movement was impaired.

Of thirty knee joints in the rest group with a normal range of movement, two showed a loss of $20^{\circ}$ or more at Week 12 . Of 32 knee joints in which movement was impaired on admission, eighteen showed an increase of $10^{\circ}$ or more (56 per cent.) by Week 12 , and four ( $12 \cdot 5$ per cent.) showed a decrease.

Among the controls, movement had decreased at Week 12 in three out of 23 knee joints which had a full range on admission. Of 39 knees in which movement was impaired on admission, sixteen (41 per cent.) had gained $10^{\circ}$ or more by Week 12, and in ten (26 per cent.) movement had decreased.

Table VI also presents the results for the elbow joints. At Week 1222 (61 per cent.) out of 36 elbows with impaired movement on admission had increased their range of movement by $10^{\circ}$ or more. Among the controls, nineteen (56 per cent.) out of 34 elbows with impaired movement had increased

TABLE $\mathbf{V}$

CHANGES IN MEAN RANGE OF JOINT MOVEMENT BETWEEN ASSESSMENTS

\begin{tabular}{|c|c|c|c|c|c|c|c|c|c|}
\hline \multirow{2}{*}{ Group } & \multirow{2}{*}{\multicolumn{5}{|c|}{ Time of Assessment }} & \multicolumn{4}{|c|}{ Mean Range in Degrees \pm S.D. } \\
\hline & & & & & & Wrists & Elbows & Knees & Ankles \\
\hline \multirow{4}{*}{ Rest } & Admission & .. & . & .. & $\cdots$ & $83 \pm 28$ & $139 \pm 22$ & $125 \pm 25$ & $66 \pm 12$ \\
\hline & Week 6 & .. & . & .. & $\ldots$ & $82 \pm 28$ & $142 \pm 22$ & $123 \pm 34$ & $70 \pm 16$ \\
\hline & Week 12 & $\ldots$ & $\ldots$ & .. & . & $83 \pm 25$ & $146 \pm 19$ & $128 \pm 27$ & $72 \pm 14$ \\
\hline & Week 24 & .. & . & .. & .. & $83 \pm 27$ & $144 \pm 22$ & $130 \pm 21$ & $72 \pm 13$ \\
\hline \multirow{4}{*}{ Control } & Admission & .. & . & .. & .. & $86 \pm 38$ & $145 \pm 17$ & $124 \pm 33$ & $68 \pm 15$ \\
\hline & Week 6 & . & . & . & $\cdots$ & $87 \pm 34$ & $150 \pm 13$ & $127 \pm 35$ & $71 \pm 11$ \\
\hline & Week 12 & . & $\ldots$ & . & $\ldots 1$ & $86 \pm 31$ & $149 \pm 18$ & $123 \pm 36$ & $73 \pm 13$ \\
\hline & Week 24 & $\ldots$ & . & .. & $\ldots$ & $87 \pm 33$ & $147 \pm 14$ & $123 \pm 33$ & $72 \pm 11$ \\
\hline
\end{tabular}


TABLE VI

CHANGE IN RANGE OF MOVEMENT OF KNEE AND ELBOW JOINTS BETWEEN ADMISSION AND WEEK 12 (FULL MOVEMENT - $140^{\circ}-$ )

\begin{tabular}{|c|c|c|c|c|c|c|c|c|c|c|}
\hline \multirow{2}{*}{ Joint } & \multirow{2}{*}{ Group } & \multirow{2}{*}{\multicolumn{3}{|c|}{$\begin{array}{l}\text { Range of } \\
\text { Movement on } \\
\text { Admission }\end{array}$}} & \multirow{3}{*}{$\begin{array}{c}\begin{array}{c}\text { No. of } \\
\text { Joints } \\
\text { Measured }\end{array} \\
30\end{array}$} & \multicolumn{5}{|c|}{ Movement at Week 12} \\
\hline & & & & & & $\underset{20^{\circ}}{\text { Gain }}$ & $\begin{array}{l}\text { Gain } \\
10^{\circ}-19^{c}\end{array}$ & $\begin{array}{c}\text { No } \\
\text { Change }\end{array}$ & $\begin{array}{c}\text { Decrease } \\
10^{\circ}-19^{\circ}\end{array}$ & Decrease \\
\hline \multirow{4}{*}{ Knee } & \multirow{2}{*}{ Rest } & Full .. & $\cdots$ & $\cdots$ & & - & - & 28 & - & 2 \\
\hline & & Impaired & . & $\cdots$ & 32 & 10 & 8 & 10 & - & 4 \\
\hline & \multirow{2}{*}{ Control } & Full .. & $\cdots$ & $\cdots$ & 23 & - & - & 20 & 3 & $\cdots$ \\
\hline & & Impaired & $\cdots$ & $\cdots$ & 39 & 7 & 9 & 13 & 6 & 4 \\
\hline \multirow{4}{*}{ Elbow } & \multirow{2}{*}{ Rest } & Full .. & $\cdots$ & . & 26 & - & - & 23 & 2 & 1 \\
\hline & & Impaired & $\cdots$ & $\cdots$ & 36 & 12 & 10 & 11 & 3 & - \\
\hline & \multirow{2}{*}{ Control } & Full .. & $\cdots$ & $\cdots$ & 28 & - & - & 25 & 3 & - \\
\hline & & Impaired & . & $\ldots$ & 34 & 6 & 13 & 12 & 2 & 1 \\
\hline
\end{tabular}

their range by $10^{\circ}$ or more by Week 12 . The range of movement had decreased in six joints in each group.

Similar results to the above were recorded for movement in the ankle and wrist joints in each group.

The range of movement of some individual joints of patients in both groups varied from assessment to assessment, and the increase and decrease of movement recorded in Table VI did not necessarily persist at that level. Table VII gives the number of joints showing an increase or decrease of $20^{\circ}$ or more that was sustained throughout the 24 weeks.

TABLE VII

JOINTS SHOWING A SUSTAINED GAIN OR LOSS OF MOVEMENT OF $20^{\circ}$ OR MORE AT WEEKS 12 AND 24

\begin{tabular}{|c|c|c|c|c|c|c|}
\hline \multirow{2}{*}{ Joints } & \multicolumn{3}{|c|}{ Rest } & \multicolumn{3}{|c|}{ Control } \\
\hline & Gain & $\begin{array}{c}\text { No } \\
\text { Change }\end{array}$ & Loss & Gain & $\begin{array}{c}\text { No } \\
\text { Change }\end{array}$ & Loss \\
\hline Wrists & 9 & 46 & 7 & 7 & 47 & 8 \\
\hline Elbows & 7 & 54 & 1 & 3 & 59 & 0 \\
\hline Knees & 7 & 51 & 4 & 5 & 52 & 5 \\
\hline Ankles & 11 & 49 & 2 & 9 & 50 & 3 \\
\hline Total & 34 & 200 & 14 & 24 & 208 & 16 \\
\hline
\end{tabular}

The numerical advantage in Table VI and VII lay with the rest group, but the differences between the two groups did not reach a statistically significant level.

Strength of Grip (Table VIII, opposite).-There was very little decrease in power of grip after 4 weeks immobilization. In eight of the 24 patients strength of grip had increased, although the mean value had fallen slightly $(212 \pm 120)$. Thereafter, a significant increase in strength of grip occurred in the rest group $(p<0.05)$, which reached a maximum at Week 12 and was sustained at Week 24.

A smaller increase in strength of grip occurred in the control group which was not statistically significant at any assessment. The difference between the mean increase in strength of grip of the rest and control groups did not reach a statistically significant level.

Functional Capacity (Table VIII). - No assessment was made at Week 4 as both groups had been confined to bed up to this point.

On admission a slightly higher proportion of the patients allocated to the control group were in the lower two grades of functional capacity. At Week 6 , four patients in the rest group were still confined to bed and eleven were in the lower two grades, compared with six in the control group. By Week 12 the numbers in the lower two grades were similar, and by Week 24 none of the patients in the rest group remained in Grade IV. Improvement in functional capacity was noted in patients in both groups. Eight patients in the rest group and five in the control group were fit for all normal activities by Week 24 .

Disease Activity (Table VIII).-On admission all patients in both groups showed moderate or marked activity. A significant decrease in activity occurred in both groups. This was most marked in the control 
TABLE VIII

CHANGES IN MEAN GRIP STRENGTH, GRADE OF FUNCTIONAL CAPACITY, GRADE OF DISEASE ACTIVITY, HAEMOGLOBIN AND ERYTHROCYTE SEDIMENTATION RATE BETWEEN ASSESSMENTS

\begin{tabular}{|c|c|c|c|c|c|c|c|c|c|c|c|c|c|}
\hline \multirow{2}{*}{ Group } & \multirow{2}{*}{$\begin{array}{l}\text { Time of } \\
\text { Assessment }\end{array}$} & \multicolumn{3}{|c|}{$\begin{array}{l}\text { Mean Grip Strength } \\
\text { (mm. Hg) }\end{array}$} & \multicolumn{4}{|c|}{$\begin{array}{c}\text { Grade of } \\
\text { Functional Capacity }\end{array}$} & \multicolumn{3}{|c|}{$\begin{array}{c}\text { Grade of } \\
\text { Disease Activity }\end{array}$} & \multirow[t]{2}{*}{$\begin{array}{l}\text { Mean } \\
\text { Haemoglobin } \\
\text { (per cent.) } \\
\pm \text { S.D. }\end{array}$} & \multirow[t]{2}{*}{$\begin{array}{l}\text { Mean } \\
\text { E.S.R. } \\
\text { (mm./1 hr) } \\
\pm \text { S.D. }\end{array}$} \\
\hline & & $\begin{array}{l}\text { Right } \\
\text { Hand }\end{array}$ & $\begin{array}{l}\text { Lef t } \\
\text { Hand }\end{array}$ & $\begin{array}{l}\text { Both } \\
\text { Hands }\end{array}$ & I & II & III & IV & I & II & III & & \\
\hline \multirow{4}{*}{ Rest } & Admission & 119 & 111 & $230 \pm 97$ & 0 & 22 & 8 & 1 & 一 & 27 & 4 & $87 \pm 11$ & $45 \pm 23$ \\
\hline & Week 6 & 146 & 145 & $291 \pm 116$ & 1 & 19 & 7 & 4 & 8 & 21 & 2 & $89 \pm 8$ & $31 \pm 20$ \\
\hline & Week 12 & 161 & 158 & $319 \pm 124$ & 6 & 19 & 4 & 2 & 12 & 18 & 1 & $90 \pm 8$ & $33 \pm 24$ \\
\hline & Week 24 & 153 & 148 & $301 \pm 132$ & 8 & 16 & 7 & 0 & 13 & 16 & 2 & $93 \pm 8$ & $30 \pm 22$ \\
\hline \multirow{4}{*}{ Control } & Admission & 117 & 114 & $231 \pm 120$ & 0 & 19 & 10 & 2 & - & 26 & 5 & $82 \pm 10$ & $52 \pm 24$ \\
\hline & Week 6 & 141 & 153 & $274 \pm 114$ & 1 & 24 & 4 & 2 & 10 & 20 & 1 & $85 \pm 8$ & $35 \pm 24$ \\
\hline & Week 12 & 142 & 139 & $281 \pm 124$ & 4 & 21 & 5 & 1 & 6 & 23 & 2 & $87 \pm 10$ & $39 \pm 24$ \\
\hline & Week 24 & 135 & 140 & $275 \pm 117$ & 5 & 21 & 3 & 2 & 5 & 22 & 4 & $86 \pm 10$ & $42 \pm 19$ \\
\hline
\end{tabular}

group at Week 6; thereafter activity in this group showed an increase.

The rest group showed a steady decrease in activity from admission to Week 24 , when thirteen patients in the rest group, but only five in the control group were considered to be inactive. The difference between the numbers of active and inactive patients in the two groups at Week 24 favoured the rest group, but the difference was not statistically significant $\left(\chi^{2}=3 \cdot 83 ; n=1\right)$.

Sensitized Sheep Cell Agglutination Test.-No significant changes were noted during the period of observation.

Haemoglobin (Table VIII).-The mean haemoglobin was lower in the control group (82 per cent.) on admission than in the rest group (87 per cent.). There was no significant difference between the small percentage rise seen in both groups. At Week 24, however, the mean haemoglobin level in the rest group was significantly higher than on admission $(p<0.05)$.

Erythrocyte Sedimentation Rate (Table VIII).Both groups showed a significant fall in E.S.R. between admission and Week $6(p<0.05)$ which was sustained at Week 12 in both groups, but only in the rest group at Week 24. There was a significant difference between the groups at Week 24, the advantage lying with the rest group $(p<0.05)$. However, the difference between the mean fall in E.S.R. which occurred in both groups was not statistically significant.
The E.S.R. was over $60 \mathrm{~mm}$. in 1 hour (Westergren) in eleven patients in each group. An analysis of the progress of these patients is shown in the Figure (overleaf).

Rest Group.-The fall in E.S.R. after the first 4 weeks in hospital was more marked in the eleven patients in the rest group, although the disease had become inactive in only one of them at this stage. By Week 24 it had become completely inactive in five patients ( 45 per cent.); in four others it had again become very active, and two showed moderate activity. A similar trend is seen in the haemoglobin level, which had risen to over 100 per cent. in four patients, and to over 90 per cent. in seven.

Control Group.-The fall in E.S.R. was not as marked in the patients in the control group after 4 weeks in hospital; seven of the eleven patients still showed E.S.R.s of $60 \mathrm{~mm} . / 1 \mathrm{hr}$ or more, compared with only two in the rest group. At Week 24 the disease was inactive in only one patient (9 per cent.). In five patients the haemoglobin level had risen to over 90 per cent., and in none had it risen to 100 per cent. or more.

\section{Complications}

Rest Group.-On the whole the period of complete immobilization was well tolerated by the patients. After a few days almost all the patients in this group became free from pain.

Two patients were uncuffed after only 3 weeks' immobilization. One woman, aged 34 , had considerable difficulty with micturition but was otherwise well. The other, a woman aged 59, developed 

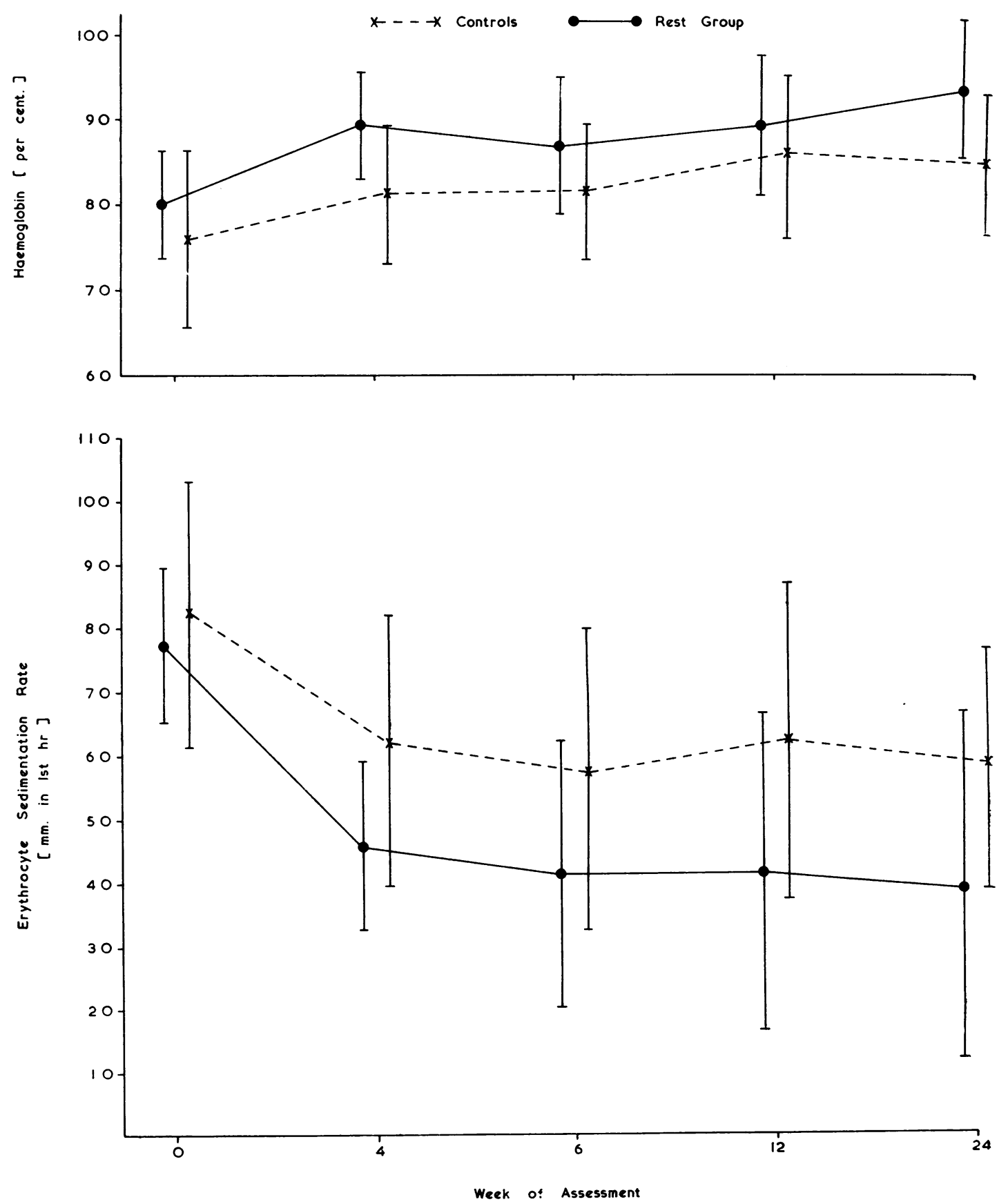

Figure.-Changes in mean haemoglobin level and erythrocyte sedimentation rate in patients with an initial E.S.R. level of over $60 \mathrm{~mm}$. in the first hour. The mean values and standard deviations are shown of eleven observations in each group at each assessment. 
congestive cardiac failure as a result of hypertension and ischaemic heart disease. She made a satisfactory recovery, however, accompanied by considerable improvement in her arthritic symptoms.

The other complications occurred after the period of immobilization had been terminated. Two patients developed mild episodes of calf vein thrombosis which rapidly subsided. One patient with known pulmonary fibrosis developed acute bronchitis. Two other patients developed more serious illnesses which considerably lengthened their stay in hospital: a man aged 64 developed pneumonia followed by empyema accompanied by an acute flare-up of disease activity in the joints shortly after the splints were removed; a woman aged 62 developed a coronary occlusion followed by pulmonary infarction and chest infection. Both patients eventually made a satisfactory recovery.

Control Group.- A man aged 56 had an acute exacerbation of chronic bronchitis with cardiac failure during the first 4 weeks of treatment. There were no other complicating illnesses in this group.

\section{Weight}

No significant changes in weight were noted in either group during their stay in hospital.

\section{Discussion}

The main objectives of the trial were:

(a) To ascertain the effects on function of a period of complete immobilization of actively inflamed joints;

(b) To assess the effects of immobilization of all affected joints on disease activity and overall functional capacity in patients with rheumatoid arthritis;

(c) To compare the results of this form of treatment with those of a more conventional regimen of bed rest and intermittent splinting of the affected joints.

With regard to the first objective, it is clear that in the majority of cases only transient limitation of movement followed a period of 4 weeks complete immobilization, and this was rapidly regained after removal of the splints. In a few patients in both groups minor decreases in movement occurred during treatment without significant effect on function. Where movement was initially impaired, improvement occurred in a number of joints in both groups.

Strength of grip was used as an index of muscular strength as well as a measure of function in the hands and wrists. It might have been anticipated that considerable diminution of power would follow 4 weeks' disuse, but the decrease was remarkably small, and a substantial increase over the initial values followed the resumption of activity. The improvement in strength of grip that occurred in the rest group during the 24 weeks was more than that expected to occur by chance, whereas the improvement in grip strength in the control group was not. A comparison of the mean improvement in each group was not, however, statistically significant.

Immobilization of all affected joints was technically difficult to achieve and no attempt was made to immobilize the shoulders and hips. In practice, however, very little use was made of these joints by the patients during the 4 weeks' period of immobilization in bed.

Improvement in overall functional capacity and disease activity occurred in both groups. Although the difference between the two groups did not reach a significant level, the advantage in numbers always favoured the rest group. In respect of mean haemoglobin level and mean erythrocyte sedimentation rate, the difference between the two groups at Week 24 was significant, although it should be noted that the mean values for haemoglobin and E.S.R. in the control group indicated a greater degree of disease activity on admission.

A greater difference was observed between the patients in each group who were clinically the most active and whose E.S.R. level was initially above $60 \mathrm{~mm}$. in the first hour. At Week 4 the E.S.R. had fallen to below 60 in nine patients out of eleven in the rest group compared with only four out of eleven in the control group. From then until Week 24 a progressive fall in E.S.R. occurred in seven of the eleven patients in the rest group, in five of whom the disease became completely inactive. By contrast, in only one patient in the control group had the disease become inactive at this assessment.

The diminution of disease activity is also reflected in the more marked rise in haemoglobin level among the eleven immobilized patients.

The incidence of complications arising during treatment was higher among patients in the rest group, and it is probable that such prolonged periods of immobilization should not be used in elderly patients.

The numbers in this trial are small, and this made the results difficult to evaluate, particularly on a statistical level. The overall impression was one of greater improvement in a number of respects in patients who had been immobilized. Improvements in the rest group often reached and sustained 
a level which was significantly different from the levels observed on admission values, whereas those in the control group did not. These improvements were not sufficiently great, however, to produce a significant difference between the two groups.

Too much stress cannot be placed on the results of this limited trial, but it can be said with reasonable assurance that periods of complete immobilization of actively inflamed joints can be used in the treatment of rheumatoid arthritis with considerable benefit. Local symptoms are rapidly controlled and systemic signs of disease activity tend to decrease. It is clearly unnecessary to insist on daily active movements of painful joints in order to prevent ankylosis.

\section{Summary}

(1) A clinical trial has been conducted to assess the value and possible hazards of a period of complete immobilization of the joints in the treatment of rheumatoid arthritis.

(2) In 34 patients the joints were immobilized by unpadded plaster splints fixed in position by circular cuffs for a period of 4 weeks. No physiotherapy was given during this period which was followed by gradual resumption of movement.

(3) 34 patients who were confined to bed for 4 weeks, but who performed active movements daily, served as controls.

(4) Improvement in range of movement in the affected joints and in functional capacity occurred in both groups.

(5) The diminution of disease activity was more marked in the group of patients who had their joints completely immobilized and was particularly noticeable in those patients who started with very severe inflammation.

(6) No joint ankylosis occurred in any patient during the course of this trial.

(7) It is suggested that a period of complete immobilization can safely be used in the treatment of rheumatoid arthritis to control pain, muscle spasm, and disease activity.

We wish to express our thanks to Miss S. H. Cameron, Superintendent Physiotherapist, Northern General Hospital, Edinburgh, for carrying out the measurements of the range of joint movements in the patients in this series.

While this work was done, the Rheumatic Diseases Unit was in receipt of grants from the Medical Research
Council, Empire Rheumatism Council, Nuffield Foundation, and Boots Pure Drug Ltd.

\section{REFERENCES}

Ball, J. (1950). Lancet, 2, 520.

Duthie, J. J. R. (1951). Practitioner, 166, 22.

(1952). J. Bone Jt Surg., 34B, 211.

- Brown, P. E., Knox, J. D. E., and Thompson, M. (1957). Ann. rheum. Dis., 16, 411.

Hunter, J. (1835). "The Works of John Hunter, F.R.S.", ed. J. F. Palmer. Longman, Rees, Orme, Brown, Green, and Longman, London.

Jones, R. (1909). Brit. med. J., 2, 2.

Kelly, M. (1953). Med. J. Aust., $2,95$.

- (1956). N.Z. med. J., 55, 11.

- (1957). Acta rheum. scand., 3, 203.

(1960). Docum. Geigy Acta rheumatologica, No. 6

Kindersley, C. E. (1936). Proc. roy. Soc. Med., 29, 237.

Richmond, J., Gardner, D. L., Roy, L. M. H., and Duthie, J. J. R. (1956). Ann. rheum. Dis., 15, 217.

Ropes, M. W., Bennett, G. A., Cobb, C., Jacox, R., and Jessar, R. A. (1959). Ibid., 18, 49.

Swaim, L. T. (1934). J. Amer. med. Ass., 103, 1589.

Swanson, N. (1956). Canad. med. J., 75, 257.

Thomas, H. O. (1878). "Diseases of the Hip, Knee, and Ankle Joints, with their Deformities, treated by a New and Efficient Method", 3rd ed. Lewis, London.

Essai contrôlé de l'effet de l'immobilisation complète des articulations dans l'arthrite rhumatismale

\section{RÉSUMÉ}

(1) On a entrepris un essai clinique pour estimer la valeur et le danger d'une période d'immobilisation complète des articulations dans le traitement de l'arthrite rhumatismale.

(2) Chez 34 malades les articulations furent immobilisées par des attelles de plâtre, sans rembourrage, maintenues en position par des manchons circulaires pendant 4 semaines. On n'appliqua pas de physiothérapie pendant cette période, qui fut suivie d'une mobilisation progressive.

(3) Comme témoins, on eut 34 malades alités pendant 4 semaines, mais qui effectuaient des mouvements actifs tous les jours.

(4) Une amélioration de l'amplitude des mouvements des articulations affectées et de la capacité fonctionnelle fut notée dans les deux groupes.

(5) Une diminution de l'activité morbide fut plus prononcée dans le groupe des malades dont les articulations avaient été complètement immobilisées et cet effet fut particulièrement marqué chez ceux qui avaient débuté par une inflammation très sévère.

(6) On n'observa d'ankylose chez aucun malade pendant cet essai.

(7) On pense qu'une période d'immobilisation complète peut-être appliquée sans crainte dans le traitement de l'arthrite rhumatismale pour maitriser la douleur, le spasme musculaire et l'activité morbide. 
Estudio controlado del efecto de la inmovilización completa de las articulaciones en la artritis reumatoide

\section{SUMARIO}

(1) Se llevó a cabo un ensayo clínico para estimar el valor y los riesgos de un periódo de inmovilización completa de las articulaciones en el tratamiento de la artritis reumatoide.

(2) En 34 enfermos las articulaciones se inmovilizaron con férulas de yeso sin amohadillar, fijadas en posición por bandas circulares por períodos de 4 semanas. No se administró ninguna terapéutica física durante este período, que fué seguido por una movilización gradual.

(3) Otros 34 pacientes, encamados por 4 semanas, pero realizando movimientos activos todos los dias sirvieron de testigos.
(4) Una mejoría en la amplitud de los movimientos de las articulaciones afectas y en la capacidad funcional ocurrió en ambos grupos.

(5) La disminución de la actividad mórbida fué más pronunciada en el grupo de enfermos cuyas articulaciones fueron inmovilizadas completamente y más ostensible en los que habían empezado con una inflamación muy severa.

(6) No se observó anquilosis en ningún enfermo durante este ensayo.

(7) Se sugiere que un período de inmovilización completa se puede usar sin temor en el tratamiento de la artritis reumatoide para controlar el dolor, el espasmo muscular y la actividad mórbida. 